\title{
Analisis Faktor-Faktor yang Mempengaruhi Pengungkapan Islamic Social Reporting pada Perusahaan yang Terdaftar di Jakarta Islamic Index Periode 2010-2013
}

\author{
(Analysis Determinants Of Disclosure Islamic Social Reporting Among List Of Jakarta \\ Islamic Index Companies Period 2010-2013)
}

\author{
Tantri Puji Rahayu, Agung Budi S.* \\ Jurusan Akuntansi, Fakultas Ekonomi, Universitas Jember (UNEJ) \\ Jln. Kalimantan 37, Jember 68121 \\ E-mail: tantrirahayu09@gmail.com
}

\begin{abstract}
Abstrak
Islamic Social Reporting (ISR) merupakan indeks pengungkapan tanggung jawab sosial yang indikatornya spesifik pada prinsip-prinsip etis Islam. Dalam penelitian ini, penilaian tingkat pengungkapan ISR dilakukan pada perusahaan yang masuk dalam Jakarta Islamic Index. Penelitian ini bertujuan untuk memperoleh bukti empiris mengenai analisis faktor-faktor yang mempengaruhi pengungkapan Islamic Social Reporting (ISR). Faktor-faktor yang digunakan antara lain ukuran perusahaan, profitabilitas, dan kinerja lingkungan hidup. Pengukuran Islamic Social Reporting (ISR) didasarkan pada kategori Islamic Social Reporting untuk mengukur indeks ISR yang dilihat dari laporan tahunan perusahaan. Penelitian ini merupakan penelitian kuantitatif. Populasi pada penelitian ini adalah perusahaan yang terdaftar di Jakarta Islamic Index yang berjumlah 30 perusahaan syariah. Teknik sampling yang digunakan adalah purposive sampling. Total sampel adalah 8 perusahaan syariah. Analisis data dilakukan dengan uji asumsi klasik dan pengujian hipotesis dengan metode regresi berganda. Hasil penelitian ini menunjukkan bahwa faktor kinerja lingkungan hidup berpengaruh signifikan terhadap pengungkapan Islamic Social Reporting. Sedangkan ukuran perusahaan dan profitabilitas tidak berpengaruh secara signifikan terhadap pengungkapan Islamic Social Reporting di Indonesia. Implikasi penelitian ini diharapkan mampu memberikan kontribusi teoritis berkaitan dengan pengungkapan tanggung jawab sosial Islam dan secara praktis bermanfaat memberikan masukan bagi para pengambil kebijakan dan regulator di Bursa Efek Indonesia.
\end{abstract}

Kata Kunci: Islamic Social Reporting, Jakarta Islamic Index, ukuran perusahaan, profitabilitas dan kinerja lingkungan hidup

\begin{abstract}
Islamic Social Reporting (ISR) is a social responsibility disclosure index that has specific indicators on ethical principles of Islam. In this study, assessment a level of ISR disclosure performed among list of Jakarta Islamic Index companies. The aim of this study is to obtain an empirical evidence about factor that affect Islamic Social Reporting (ISR) in company's annual report. The factors that used in this study such as:social activity, industry size, profitability, and environmental performance. Measurement of Islamic Social Reporting is based on islamic social reporting categories that used to calculate the Islamic Social Reporting Index as seen from the company's annual report. This research is a quantitative research. The population of this research are all companies that listed in Jakarta Islamic Index totaling 30 companies. Sampling technique used purposive sampling technique. Total sample was 8 companies. The analytical techniques was conducted by multiple regression method and also classical assumption test. The results of this study indicate that the industry size significantly positive influence the Islamic Social Reporting (ISR) disclosure. Meanwhile, profitability and environmental performance had no significant effect to the Islamic Social Reporting (ISR) disclosure in Indonesia.
\end{abstract}

Keywords: Islamic Social Reporting, Jakarta Islamic Index industry size, profitability, and environmental performance.

\section{Pendahuluan}

Tanggung jawab sosial atau sering disebut sebagai Corporate Social Responsibility (CSR) merupakan wacana yang makin umum dalam dunia bisnis di Indonesia dimana fenomena ini dipicu oleh semakin mengglobalnya tren mengenai praktek CSR dalam bisnis. Konsep CSR dalam Islam erat kaitannya dengan perusahaan-perusahaan yang menjalankan kegiatan bisnis sesuai dengan konsep syariah yang berharap perusahaan dapat melakukan tanggung jawab sosial perusahaan secara Islami. Perkembangan CSR dalam ekonomi Islam juga berdampak pada meningkatnya perhatian masyarakat terhadap instansi-instansi atau lembaga syariah. Meningkatnya perhatian masyarakat mengindikasikan bahwa kebutuhan masyarakat terhadap lembaga atau instansi syariah semakin besar dari waktu ke waktu.
Di Indonesia, perkembangan pasar modal syariah diawali dengan dibentuknya Jakarta Islamic Index (JII). Jakarta Islamic Index terdiri atas 30 saham syariah yang tercatat di Bursa Efek Indonesia (BEI). Othman dan Thani (2010) memaparkan bahwa perkembangan pasar modal syariah yang begitu cepat membuat perusahaan-perusahaan yang masuk pada Jakarta Islamic Index (JII) diekspektasikan untuk menyajikan suatu dimensi religi dalam pengungkapan laporan tahunan yang bertujuan untuk memberi manfaat bagi pemangku kepentingan muslim. Oleh karena itu, dibutuhkan acuan untuk mengukur sejauh mana perusahaan-perusahaan yang terdaftar di Jakarta Islamic Index (JII) membuat laporan tanggung jawab sosial yang turut menyajikan aspek-aspek religi dalam laporan tahunan dengan menyajikan pemenuhan kewajiban perusahaan yang sesuai dengan syariah. Othman et al. (2009) mengembangkan indeks pengungkapan yang relevan pada Islamic Social Reporting (ISR) Index.

* Corresponding Author 
Indeks ISR merupakan tolak ukur pelaksanakaan tanggung jawab sosial perusahaan syariah yang berisi kompilasi itemitem standar CSR yang ditetapkan oleh AAOIFI (Accounting and Auditing Organization for Islamic Financial Institutions) yang dikembangkan lebih lanjut oleh para peneliti mengenai item-item CSR yang seharusnya diungkapkan oleh suatu entitas Islam (Othman et al, 2009). ISR pertama kali dikemukakan oleh Haniffa (2002) lalu dikembangkan secara lebih ekstensif oleh Othman et al. (2009) di Malaysia. Haniffa (2002) mengungkapkan bahwa adanya keterbatasan dalam pelaporan sosial konvensional sehingga ia mengemukakan kerangka konseptual Islamic Social Reporting berdasarkan ketentuan syariah yang tidak hanya membantu pengambilan keputusan bagi pihak muslim melainkan juga untuk membantu perusahaan dalam melakukan pemenuhan kewajibannya terhadap Allah SWT dan masyarakat.

Pelaporan sosial syariah atau Islamic Social Reporting (ISR) masih bersifat sukarela sehingga pelaporan CSR setiap perusahaan syariah menjadi tidak sama. Pelaporan yang tidak sama tersebut disebabkan tidak adanya standart yang baku secara syariah tentang pelaporan CSR syariah. Pengukuran CSR masih mengacu kepada Global Reporting Initiative Index (Indeks GRI) dimana pengukuran tersebut tentunya kurang tepat karena perusahaan yang diakui sebagai emiten syariah dan dinyatakan memenuhi syariat Islam seharusnya mengungkapkan informasi yang membuktikan perusahaan tersebut beroperasi sesuai hukum Islam dimana dengan menggunakan indeks GRI belum menggambarkan prinsipprinsip Islam seperti belum mengungkapkan terbebasnya dari unsur riba, gharar, dan transaksi-transaksi yang diharamkan oleh Islam.

Indeks ISR untuk entitas Islam mengungkapkan hal-hal yang berkaitan dengan prinsip Islam seperti transaksi yang sudah terbebas dari unsur riba, spekulasi dan gharar, serta mengungkapkan zakat, status kepatuhan syariah serta aspekaspek sosial seperti sadaqah, waqaf, qardul hasan, dan pengungkapan peribadahan di lingkungan perusahaan.

Penelitian mengenai pelaksanaan ISR masih berorientasi di sektor perbankan syariah, seperti penelitian Fitria dan Hartanti (2010), Zubairu (2011), Rizkiningsih (2012), Sofyani (2012), Khoirudin (2013), dan Fauziah (2013). Penelitian mengenai ISR untuk sektor non perbankan dan lembaga keuangan lainnya seperti pasar modal syariah masih belum banyak dilakukan sehingga kurang meluasnya konsep ISR terutama di Indonesia. Pasar modal syariah yang tumbuh pesat ditambah maraknya praktek pengungkapan CSR yang seharusnya sebagai pelaku ekonomi syariah dan emiten syariah juga harus melaporkan tanggung jawab sosial yang berbasis syariah. Berkembangnya CSR menjadi wacana bahwa perusahaan di emiten syariah masih mengungkapkan CSR-nya, sehingga peneliti mencoba mengarahkan tanggung jawab sosial berbasis syariah menggunakan ISR.

Salah satu faktor yang mempengaruhi pengungkapan ISR adalah ukuran perusahaan merupakan tingkat identifikasi besar atau kecilnya suatu perusahaan. Perusahaan yang besar biasanya memiliki aktivitas yang lebih banyak dan kompleks, mempunyai dampak yang lebih besar terhadap masyarakat, memiliki shareholder yang lebih banyak, serta mendapat perhatian lebih dari kalangan publik sehingga perusahaan besar cenderung mendapat tekanan yang lebih untuk mengungkapkan pertanggungjawaban sosialnya. Fakta ini dibuktikan dengan penelitian yang dilakukan Widiawati dan Raharja (2012), Othman et al. (2009) dan Raditya (2012), serta Haniffa dan Cooke (2005) yang menemukan hubungan positif ukuran perusahaan terhadap ISR dimana perusahaan yang memiliki ukuran perusahaan yang besar biasanya akan mengungkapkan lebih daripada perusahaan kecil. Penelitian Karina (2013), Adawiyah (2013) dan penelitian Anggraini (2006) menemukan bahwa ukuran perusahaan tidak berpengaruh terhadap luasnya pengungkapan tanggung jawab sosial.

Profitabilitas juga mempengaruhi pengungkapan ISR dimana perusahaan yang memiliki kondisi keuangan yang kuat akan mendapatkan tekanan yang lebih dari pihak ekternal perusahaan untuk lebih mengungkapkan pertanggungjawaban sosialnya secara luas. Suatu perusahaan yang memiliki profit lebih besar harus lebih aktif melaksanakan CSR (Amran dan Devi, 2008). Namun, pada kenyataannya beberapa perusahaan dengan profit besar cenderung tidak melakukan CSR dengan baik. Penelitian Raditya (2012), Dahlia dan Siregar (2008) serta Widiawati (2012) menemukan bahwa pengaruh profitabilitas terhadap ISR berpengaruh positif dan signifikan. Namun, dalam penelitian Suta dan Laksito (2012) serta Wijaya (2012) menghasilkan bahwa profitabilitas tidak berpengaruh terhadap luas informasi pada pengungkapan tanggung jawab sosial perusahaan.

Kinerja lingkungan hidup mempengaruhi pengungkapan ISR sesuai penelitian Sudaryanto (2011), Rahmawati dan Achmad (2012) serta Rakhiemah dan Dian Agustia (2009) menyatakan bahwa kinerja lingkungan hidup berpengaruh positif terhadap pengungkapan tanggung jawab sosial perusahaan. Namun, penelitian Wijaya (2012) yang menganalisis pengaruh kinerja lingkungan hidup terhadap pengungkapan tanggungjawab sosial, menghasilkan bahwa kinerja lingkungan hidup memiliki pengaruh yang tidak signifikan terhadap pengungkapan tanggung jawab sosial. Kinerja lingkungan hidup diukur melalui PROPER (Program Penilaian Penilaian Peringkat Kinerja Perusahaan dalam Pengelolaan Lingkungan Hidup) dengan menggunakan warna, mulai dari yang terbaik emas, hijau, biru, merah, hingga yang terburuk hitam kemudian diumumkan secara rutin kepada masyarakat agar masyarakat dapat mengetahui tingkat penataan pengelolaan lingkungan pada perusahaan dengan hanya melihat warna yang ada. Perusahaan yang ikut PROPER dan sudah melakukan kinerja lingkungan hidup yang baik, maka pengungkapan tanggung jawab sosialnya akan semakin besar.

Uraian-uraian diatas menggambarkan terdapat pengaruh yang ditimbulkan oleh ukuran perusahaan, profitabilitas, dan kinerja lingkungan hidup terhadap pengungkapan Islamic Social Reporting. Berdasarkan pemikiran tersebut dan dilandasi dengan beberapa hasil penelitian yang telah ditemukan, penulis tertarik untuk melakukan penelitian mengenai "Analisis faktor-faktor yang mempengaruhi pengungkapan Islamic Social Reporting pada perusahaan yang terdaftar di Jakarta Islamic Index periode 2010-2013"

Penelitian ini memiliki 3 hipotesis. Hipotesis pertama menyatakan bahwa ukuran perusahaan berpengaruh signifikan terhadap pengungkapan Islamic Social Reporting. Hipotesis kedua menyatakan bahwa profitabilitas berpengaruh signifikan terhadap pengungkapan Islamic 
Social Reporting. Hipotesis ketiga menyatakan bahwa kinerja lingkungan hidup berpengaruh signifikan terhadap pengungkapan Islamic Social Reporting. Penelitian ini dilakukan untuk mengetahui pengaruh dari ukuran perusahaan, profitabilitas, dan kinerja lingkungan hidup terhadap pengungkapan Islamic Social Reporting.

\section{Metode Penelitian.}

\section{Rancangan Penelitian}

Penelitian ini merupakan jenis penelitian kuantitatif, yaitu penelitian dengan penekanan pada pengujian teori melalui variabel-variabel penelitian dengan angka dan melakukan analisis data dengan prosedur statistik.

\section{Jenis dan Sumber Data}

Penelitian ini emnggunakan data sekunder. Data sekunder pada penelitian ini berupa laporan tahunan (annual report) yang diterbitkan oleh perusahaan yang terdaftar di Jakarta Islamic Index pada Bursa Efek Indonesia.

\section{Populasi dan Sampel}

Populasi pada penelitian ini terdiri atas seluruh perusahaan syariah yang terdaftar di Jakarta Islamic Index yang berjumlah 30 perusahaan syariah. Pengambilan sampel menggunakan teknik purposive sampling dengan kriteria perusahaan yang tetap listed di Jakarta Islamic Index, perusahaan yang mengikuti PROPER dan perusahaan yang menerbitkan laporan tahunan sehingga total jumlah sampel dalam penelitian ini sebanyak 8 perusahaan syariah.

\section{Metode Analisis Data}

Metode analisis yang digunakan adalah analisis deskriptif statistik, uji asumsi klasik dan uji hipotesis. Uji asumsi klasik meliputi uji normalitas, uji multikolinieritas, uji heteroskedastisitas dan uji autokorelasi. Uji hipotesis yang digunakan meliputi analisis regresi berganda, uji t, uji F, dan koefisien determinasi.

\section{Hasil Penelitian}

\section{Uji Asumsi Klasik}

Uji Normalitas

Uji normalitas data dilakukan untuk mengetahui apakah data yang diperoleh berdistribusi normal atau tidak.

Tabel 1. Uji Normalitas

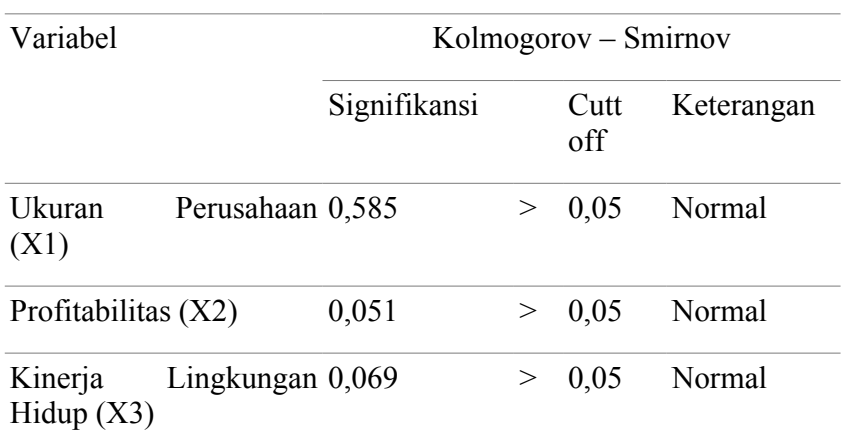

Sumber : Data diolah, April 2015

Berdasarkan tabel 1, dapat diketahui bahwa nilai probabilitas atau signifikansi untuk masing-masing variabel lebih besar dari 0,05 , sehingga dapat dinyatakan bahwa data dalam penelitian ini berdistribusi normal.

\section{Uji Multikolinearitas}

Uji multikolineritas digunakan untuk mengetahui ada atau tidaknya hubungan linear dalam variabel independen dalam model.

Tabel 2. Uji Multikolinearitas

\begin{tabular}{|c|c|c|c|c|}
\hline Test of Multikolinearity & VIF & & $\begin{array}{l}\text { Cutt } \\
\text { off }\end{array}$ & Keterangan \\
\hline Perusahaan & 1,039 & $>$ & 10 & $\begin{array}{l}\text { Tidak Terjadi } \\
\text { Multikolinearitas }\end{array}$ \\
\hline Profitabilitas (X2) & 1,163 & $>$ & 10 & $\begin{array}{l}\text { Tidak Terjadi } \\
\text { Multikolinearitas }\end{array}$ \\
\hline $\begin{array}{l}\text { Kinerja Lingkungan } \\
\text { Hidup (X3) }\end{array}$ & 0,123 & $>$ & 10 & $\begin{array}{l}\text { Tidak Terjadi } \\
\text { Multikolinearitas }\end{array}$ \\
\hline
\end{tabular}

Tabel 2, menunjukkan bahwa tidak terjadi multikolinearitas antar variabel independen karena menunjukkan nilai VIF kurang dari 10.

\section{Uji Heteroskedastisitas}

Uji heteroskedastisitas terjadi apabila distribusi probabilitas tetap sama (konstan) dalam semua observasi variabel independen dan varians setiap residual adalah sama untuk semua nilai dari variabel independen. Dalam penelitian ini, uji heteroskedastisitas yang digunakan adalah uji glejser, yaitu dengan meregresikan nilai absolut residual terhadap masing-masing variabel independen. Adapun hasil uji heteroskedastisitas disajikan pada tabel berikut :

Tabel 3. Uji Heteroskedastisitas

\begin{tabular}{|c|c|c|c|c|}
\hline \multirow{3}{*}{$\begin{array}{l}\text { Variabel } \\
\\
\text { Ukuran } \\
\text { Perusahaan } \\
\text { (X1) }\end{array}$} & \multicolumn{4}{|c|}{ Glejser } \\
\hline & Signifikansi & & Cutt off & Keterangan \\
\hline & 0,621 & $>$ & 0,05 & $\begin{array}{l}\text { Tidak terjadi } \\
\text { heteroskedastisit } \\
\text { as }\end{array}$ \\
\hline $\begin{array}{l}\text { Profitabilitas } \\
\text { (X2) }\end{array}$ & 0,018 & $<$ & 0,05 & $\begin{array}{l}\text { Terjadi } \\
\text { heteroskedastisit } \\
\text { as }\end{array}$ \\
\hline $\begin{array}{l}\text { Kinerja } \\
\text { Lingkungan } \\
\text { Hidup (X3) }\end{array}$ & 0,023 & $<$ & 0,05 & $\begin{array}{l}\text { Terjadi } \\
\text { heteroskedastisit } \\
\text { as }\end{array}$ \\
\hline
\end{tabular}

Berdasarkan tabel 3, dapat diketahui bahwa nilai probabilitas atau signifikansi untuk variabel ukuran perusahaan lebih besar dari 0,05, sehingga dapat dinyatakan bahwa data ukuran perusahaan dalam penelitian ini tidak terjadi heteroskedastisitas. Sedangkan, nilai probabilitas atau signifikansi untuk variabel profitabilitas dan kinerja lingkungan hidup lebih kecil dari 0,05, sehingga dapat dinyatakan bahwa data profitabilitas dan kinerja lingkungan hidup dalam penelitian terjadi heteroskedastisitas.

\section{Uji Autokorelasi}

Uji autokorelasi digunakan untuk mendiagnosis adanya autokorelasi dalam satu model regresi dilakukan pengujian 
terhadap nilai uji Durbin-Watson. Adapun ketentuan dari uji Durbin-Watson (Algifari, 1996) sebagai berikut :

1. Kurang dari 1,10: ada autokorelasi

2. Antara 1,10-1,54 : tanpa kesimpulan

3. Antara 1,55-2,46 : tidak ada autokorelasi

4. Antara 2,46-2,90 : tanpa kesimpulan

5. Lebih dari 2,91 : ada autokorelasi

Tabel 4. Uji autokorelasi

\begin{tabular}{ll}
\hline Model & Durbin-Watson \\
\hline 1 & 1,944
\end{tabular}

Berdasarkan tabel di atas, dapat diketahui nilai DurbinWatson Test sebesar 2,036 dari uji autokorelasi yang dilakukan dan berada pada kisaran 1,55-2,46. Berdasarkan nilai tersebut, maka dapat disimpulkan bahwa model regresi di atas tidak terdapat autokorelasi.

\section{Analisis Deskriptif Statistik}

Analisis deskriptif statistik bersifat penjelasan statistik dengan memberikan gambaran data tentang jumlah data, nilai minimum, nilai maxsimum, mean, dan standar deviasi datanya (Prayitno, 2010:12).

Tabel 3. Analisis Deskriptif Statistik

\begin{tabular}{lllll}
\hline Variabel & Minimum & Maximum & Mean & $\begin{array}{l}\text { Standar } \\
\text { Deviation }\end{array}$ \\
\hline $\begin{array}{l}\text { Ukuran } \\
\text { Perusahaan } \\
(\mathrm{X} 1)\end{array}$ & 29,347 & 31,680 & 30,289 & 0,609 \\
\hline $\begin{array}{l}\text { Profitabilitas } \\
(\mathrm{X} 2)\end{array}$ & 0,120 & 1,260 & 0,358 & 0,300 \\
\hline $\begin{array}{l}\text { Kinerja } \\
\text { Lingkungan } \\
\text { Hidup (X3) }\end{array}$ & 2,000 & 5,000 & 3,688 & 0,931 \\
& & & & \\
\hline
\end{tabular}

\section{Valid N}

Dari tabel 3 diatas, Berdasarkan tabel di atas, hasil analisis deskriptif menunjukkan bahwa rata-rata nilai ukuran perusahaan terendah sebesar 29,347 dan nilai tertinggi sebesar 31,680 dengan nilai rata-rata sebesar 30,289 dan standar deviasi sebesar 0,609. Nilai profitabilitas terendah sebesar 0,120 dan nilai tertinggi sebesar 1,260. Rata-rata nilai profitabilitas sebesar 0,358 dengan standar deviasi sebesar 0,300. Nilai kinerja lingkungan hidup terendah sebesar 2,000 dan nilai tertinggi sebesar 5,000. Rata-rata nilai kinerja lingkungan hidup sebesar 3,688 dengan standar deviasi sebesar 0,931

\section{Uji Hipotesis}

Analisis Regresi Linear Berganda

Analisis Regresi Linear Berganda digunakan untuk mengetahui seberapa besar pengaruh variabel-variabel bebas yaitu ukuran perusahaan $\left(\mathrm{X}_{1}\right)$, profitabilitas $\left(\mathrm{X}_{2}\right)$ dan kinerja lingkungan hidup $\left(\mathrm{X}_{3}\right)$ terhadap variabel terikat yaitu pengungkapan Islamic Social Reporting (Y) digunakan Analisis Regresi Linier Berganda dengan bantuan perhitungan komputer program Statistical Product and Service Solution (SPSS).

Tabel 4. Analisis Regresi Linear Berganda

\begin{tabular}{|c|c|c|c|c|c|c|c|c|}
\hline $\begin{array}{l}\text { Variabel } \\
\text { Bebas }\end{array}$ & $\begin{array}{l}\text { Koefise } \\
\mathrm{n} \\
\text { Regresi }\end{array}$ & & & $\mathrm{T}_{\text {tabel }}$ & Sig & & A & $\begin{array}{l}\text { Ketera } \\
\text { ngan }\end{array}$ \\
\hline Constan & $-0,774$ & - & - & - & - & - & - & - \\
\hline $\begin{array}{l}\text { Ukuran } \\
\text { Perusahaa } \\
\mathrm{n}(\mathrm{X} 1)\end{array}$ & 0,048 & $\begin{array}{l}2,40 \\
4\end{array}$ & $>$ & 2,052 & $\begin{array}{l}0,0 \\
23\end{array}$ & $<$ & 0,05 & $\begin{array}{l}\text { Signifi } \\
\text { kan }\end{array}$ \\
\hline $\begin{array}{l}\text { Profitabili } \\
\operatorname{tas}(\mathrm{X} 2)\end{array}$ & $-0,008$ & $\begin{array}{l}- \\
0,19 \\
2\end{array}$ & $<$ & 2,052 & $\begin{array}{l}0,8 \\
49\end{array}$ & $>$ & 0,05 & $\begin{array}{l}\text { Tidak } \\
\text { Signifi } \\
\text { kan }\end{array}$ \\
\hline $\begin{array}{l}\text { Kinerja } \\
\text { Lingkung } \\
\text { an Hidup } \\
\text { (X3) }\end{array}$ & 0,014 & $\begin{array}{l}1,07 \\
0\end{array}$ & $<$ & 2,052 & $\begin{array}{l}0,2 \\
94\end{array}$ & $>$ & 0,05 & $\begin{array}{l}\text { Tidak } \\
\text { Signifi } \\
\text { kan }\end{array}$ \\
\hline
\end{tabular}

Adjusted R Square $=0,122 \mathrm{~F}$ Hitung $=2,431$

Berdasarkan koefisien regresi, maka persamaan regresi yang dapat dibentuk adalah.

$$
Y=-0,774+0,048 X_{1}+(-0,008) X_{2}+0,014 X_{3}
$$

1. Nilai konstanta $-0,774$, menunjukkan bahwa jika tidak terdapat nilai-nilai pada variabel independen makapa pengungkapan Islamic Social Reporting sebesar -0,774

2. Nilai koefisien 0,048 pada ukuran perusahaan, menunjukkan bahwa setiap adanya ukuran perusahaan 1 satuan, maka hal tersebut akan meningkatkan pengungkapan Islamic Social Reporting sebesar 0,048, dan sebaliknya;

3. Nilai koefisien $-0,008$ pada profitabilitas, menunjukkan bahwa setiap adanya kenaikan profitabilitas 1 satuan, maka hal tersebut akan meningkatkan pengungkapan Islamic Social Reporting sebesar -0,008, dan sebaliknya;

4. Nilai koefisien 0,014 pada kinerja lingkungan hidup, menunjukkan bahwa setiap adanya kenaikan kinerja lingkungan hidup 1 satuan, maka hal tersebut akan meningkatkan pengungkapan Islamic Social Reporting sebesar 0,014, dan sebaliknya;

Uji T

Pengujian ini dilakukan untuk mengetahui apakah variabel independen berpengaruh terhadap variabel dependen secara signifikan secara parsial. Berdasarkan hasil ui t (dalam hal ini untuk menguji pengaruh secara parsial) diperoleh hasil yang dapat dinyatakan berikut ;

1. Variabel ukuran perusahaan $\left(\mathrm{X}_{1}\right)$ memiliki nilai t $2,404>$ 2,052 dan signifikasi $0,023<0,05$, maka Ho ditolak dan Ha diterima, yang berarti secara parsial variabel ukuran perusahaan berpengaruh signifikan terhadap pengungkapan Islamic Social Reporting. Selain itu thitung yang diperoleh adalah positif. 
2. Variabel profitabilitas $\left(\mathrm{X}_{2}\right)$ memiliki nilai $-0,192<2,052$ dan signifikasi $0,849<0,05$, maka Ho diterima dan Ha ditolak, yang berarti secara parsial variabel profitabilitas tidak berpengaruh signifikan terhadap pengungkapan Islamic Social Reporting.

3. Variabel kinerja lingkungan hidup $\left(\mathrm{X}_{3}\right)$ memiliki nilai $\mathrm{t}$ $1,070<2,052$ dan signifikan 0,294 < 0,05, maka Ho diterima dan Ha ditolak, yang berarti secara parsial variabel kinerja lingkungan hidup tidak berpengaruh signifikan terhadap pengungkapan Islamic Social Reporting.

Uji F

Uji F dimaksudkan untuk mengetahui pengaruh ukuran perusahaan, profitabilitas, dan kinerja lingkungan hidup terhadap variabel dependen yaitu pengungkapan Islamic Social Reporting secara simultan. Tabel distribusi F dicari pada $\alpha=5 \%$, dengan derajat kebebasan (df) df1 atau 5-1 = 4, dan df2 n-k-1 atau 32-4-1 = 27. Berdasarkan hasil analisis regresi linear berganda (dalam hal ini untuk menguji pengaruh secara simultan) diperoleh hasil, yaitu bahwa $\mathrm{F}_{\text {hitung }}>\mathrm{F}_{\text {tabel }}(2,431<2,912)$ dan signifikasi $(0,086>$ 0,05), maka Ho diterima dan Ha ditolak, artinya variabel ukuran perusahaan, profitabilitas, dan kinerja lingkungan hidup secara simultan tidak berpengaruh signifikan terhadap pengungkapan Islamic Social Reporting.

\section{Koefisien Determinasi}

Guna mengetahui besarnya proporsi atau sumbangan pengaruh variabel independen terhadap variabel dependen secara keseluruhan maka dapat ditentukan dengan uji koefisien determinasi berganda $\left(\mathrm{R}^{2}\right)$. Dilihat dari nilai koefisien determinasi berganda, hasil analisis menujukkan bahwa besarnya persentase ukuran perusahaan, profitabilitas, dan kinerja lingkungan hidup dapat dilihat dari nilai Adjusted $\mathrm{R}$ Square $\left(\mathrm{R}^{2}\right)$ menunjukkan sebesar $20,6 \%$ dan sisanya $79,4 \%$ dipengaruhi atau dijelaskan oleh faktor-faktor lain yang tidak dimasukkan dalam model penelitian ini.

\section{Pembahasan}

\section{Pengaruh Ukuran Perusahaan Terhadap Pengungkapan Islamic Social Reporting}

Ukuran perusahaan merupakan besar kecilnya suatu perusahaan yang diukur dengan total asset perusahaan. Penelitian yang dilakukan menunjukkan bahwa nilai koefisien variabel ukuran perusahaan sebesar 0,045 atau $4,5 \%$ dengan arah positif. Hal ini berarti bahwa setiap adanya kenaikan ukuran perusahaan maka akan mempengaruhi peningkatan pengungkapan Islamic Social Reporting. Apabila terdapat penurunan ukuran perusahaan maka akan mempengaruhi penurunan pengungkapan Islamic Social Reporting. Penelitian ini menemukan bahwasannya ukuran perusahaan berpengaruh signifikan terhadap pengungkapan Islamic Social Reporting. Berpengaruhnya ukuran perusahaan pengungkapan Islamic Social Reporting dapat diketahui dari total asset perusahaan sehingga semakin besar perusahaan akan melakukan pengungkapan tanggung jawab sosial yang lebih luas.

Hasil penelitian ini mendukung teori stakeholders yang menyatakan bahwa perusahaan yang besar biasanya memiliki aktivitas yang lebih banyak dan kompleks, mempunyai dampak yang lebih besar terhadap masyarakat, memiliki shareholder yang lebih banyak, serta mendapat perhatian lebih dari kalangan publik. Jadi, perusahaan syariah yang lebih besar akan cenderung untuk melakukan pengungkapan tanggung jawab sosial secara syariah lebih luas dibandingkan perusahaan syariah yang lebih kecil. Hasil penelitian ini sesuai dengan penelitian Othman et al. (2009), Raditya (2012), Hodan Wong (2001), Owusu-Ansah (1998), Haniffa dan Cooke (2005), yang membuktikan bahwa ukuran perusahaan yang diukur dengan proxy total aset mempunyai pengaruh positif terhadap tingkat pengungkapan Islamic Social Reporting. Hasil penelitian ini bertolak belakang dengan penelitian Karina (2013), Adawiyah (2013) dan Anggraini (2006) yang menyatakan bahwa ukuran perusahaan tidak berpengaruh signifikan terhadap pengungkapan Islamic Social Reporting (ISR).

\section{Pengaruh Profitabilitas Terhadap Pengungkapan Islamic Social Reporting}

Profitabilitas merupakan kemampuan perusahaan dalam mendapatkan laba. Penelitian ini menemukan bahwasannya profitabilitas tidak berpengaruh signifikan terhadap pengungkapan Islamic Social Reporting. Hal tersebut dikarenakan adanya perusahaan yang mempunyai profitabilitas tinggi belum tentu banyak melakukan aktivitas sosial karena perusahaan lebih beorientasi pada laba semata. Sedangkan pada saat perusahaan memperoleh laba yang rendah, maka terdapat persepsi bahwa pengguna laporan senang untuk membaca berita baik tentang kinerja perusahaan dalam bidang sosial.

Hasil ini konsisten dengan hasil studi Suta dan Laksito (2012) serta hasil studi Wijaya (2012) yang membuktikan bahwa profitabilitas tidak berpengaruh signifikan terhadap pengungkapan tanggung jawab sosial secara syariah.

Penelitian ini bertolak belakang dengan penelitian yang dilakukan Raditya (2012), Widiawati dan Raharja (2012) serta Dahlia dan Siregar (2008) yang membuktikan bahwa profitabilitas mempunyai pengaruh positif terhadap tingkat pengungkapan ISR.

\section{Pengaruh Kinerja Lingkungan Hidup Terhadap Pengungkapan Islamic Social Reporting}

Kinerja lingkungan hidup merupakan mekanisme perusahaan secara sukarela mengintegrasikan perhatiannya terhadap lingkungan ke dalam operasi dan interaksinya dengan stakeholders yang melebihi tanggung jawab organisasi. Penelitian ini menemukan bahwasannya kinerja lingkungan hidup tidak berpengaruh signifikan terhadap pengungkapan Islamic Social Reporting. Penyebabnya adalah pengungkapan tanggung jawab sosial syariah yang diungkapkan perusahaan yang masuk ke dalam PROPER tidak banyak diungkapkan di laporan tahunan dan kinerja lingkungan hidup untuk tahun terakhir mengalami penurunan yang diukur melalui indeks ISR.

Hasil penelitian konsisten dengan penelitian yang dilakukan oleh Wijaya (2012), yang menyatakan bahwa kinerja lingkungan hidup memiliki pengaruh yang tidak signifikan terhadap pengungkapan tanggung jawab sosial wajib maupun sukarela. Hasil penelitian ini tidak sesuai dengan penelitian yang dilakukan Aldehita (2014), Rahmawati (2012), 
Rakhiemah dan Dian Agustia (2009), serta Sudaryanto (2011) bahwa penilaian kinerja lingkungan hidup akan memberikan pengungkapan sosial wajib maupu sukarela yang lebih luas pada perusahaan.

\section{Simpulan}

\section{Kesimpulan}

Berdasarkan hasil analisis yang telah dilakukan pada penelitian ini, maka dapat ditarik kesimpulan bahwa hanya variabel ukuran perusahaan yang berpengaruh signifikan terhadap pengungkapan Islamic Social Reporting. Adapun variabel profitabilitas dan kinerja lingkungan hidup tidak mempengaruhi pengungkapan Islamic Social Reporting.

\section{Keterbatasan}

Penelitian ini memiliki beberapa keterbatasan, diantaranya bahwa jumlah sampel yang terbatas. Selanjutnya peneliti menggunakan indeks ISR yang pokok pengungkapannya merupakan hasil pengembangan dan penyesuaian penulis. Selain itu sumber informasi terbatas yaitu pada laporan tahunan perusahaan serta objek yang dipilih bukan termasuk perusahaan syariah. Agar lebih baik maka untuk penelitian selanjutnya memperluas jumlah sampel. Selain itu penelitian selanjutnya juga dapat mengembangkan pokok-pokok pengungkapan indeks ISR secara lebih komprehensif. Menambah sumber informasi pada penelitian selanjutnya dan memilih objek perbankan syariah.

\section{Referensi}

Ayu, D. F. 2010. Analisis Pengaruh Jenis Industri, Ukuran Perusahaan, dan Profitabilitas terhadap Tingkat Pengungkapan Islamic Social Reporting (ISR) pada Perusahaan yang Masuk Daftar Jakarta Islamic Index (JII) Skripsi Fakultas Ekonomi Universitas Indonesia. Depok.

Belkaoui. 1989. Determinants of the Corporate Decision to Disclose Social Information. Skripsi

Cooke, T.E. 1992. "The Impact of Size, Stock Market Listing and Industry Type on Disclosure in The Annual Reports of Japanese Listed Companies". Accounting and Business Research, Vol.19: 113-124.
Edisi Pengumuman PROPER. Press Release PROPER 2010-2013. http://proper.menlh.go.id/portal/._Diakses 11 Maret 2013

Fitria, Soraya dan Hartanti, Dwi. 2010. Islam dan Tanggung Jawab Sosial : Studi Perbandingan Pengungkapan Berdasarkan Global Reporting Iniviative Indeks dan Islamic Social Reporting Indeks. Simposium Nasional Akuntansi XIII Purwokerto

Ghozali, Imam. 2011. Aplikasi Analisis Multivariate Dengan Program SPSS. Semarang: UNDIP.

Ghozali, Imam dan Chariri, Anis. 2007. Teori Akuntansi. Badan Penerbit Universitas Diponegoro:Semarang.

Haniffa, R. 2002. Social Reporting Disclosure-An Islamic Perspective. Indonesian Management \& Accounting Research, I, 128-146.

Haniffa, R \& Cooke, T. E. 2005. The Impact of Culture and Governance on Corporate Social Reporting. Journal of Accounting and Public Policy, 24, 391-430.

Karina, L. A. D., dan Yuyetta, E. N. A. 2013. Analisis Faktor-Faktor Yang Mempengaruhi Pengungkapan CSR. Diponegoro Journal Of Accounting Volume 2, Nomor 2, Tahun 2013.

Othman, R., Thani, A. M., \& Ghani, E. K. 2009. Determinants of Islamic Social Reporting Among Top Sharia-Approved Companies in Bursa Malaysia. Research Journal of International Studies.

Raditya, Amilia Raditya. 2012. “Analisis Faktor - Faktor yang Mempengaruhi Tingkat Pengungkapan Islamic Social Reporting (ISR) pada Perusahaan yang Masuk Daftar Efek Syarih (DES)". Skripsi. Jakarta : Fakultas Ekonomi Universitas Indonesia.

Rahmawati, Ala dan Achmad, Tarmizi. 2012. Pengaruh Kinerja Lingkungan Terhadap Financial Corporate Performace dengan Corporate Social Responsibility Disclosure sebagai Variabel Intervening. Diponegoro Journal Of Accounting Volume 1 Nomor 2. Rizkiningsih, Priyesta. 2012. "Faktor-Faktor yang Mempengaruhi Pengungkapan Islamic Social Reporting (ISR) : Studi Empiris pada Bank Syariah di Indonesia, Malaysia dan Negara-Negara Gulf Cooperation Coincil”. Skripsi. Universitas Indonesia.

Widiawati, Septi dan Raharja, Surya. 2012. Analisis Faktor-Faktor yang Mempengaruhi Islamic Social Reporting Indeks Perusahaan-Perusahaan yang terdapat pada Daftar Efek Syariah Tahun 2009 - 2011. Diponegoro Journal of Accounting, Volume 1, Nomor 2.

www.idx.co.id. Diakses tanggal 11 Maret 2015. 